\title{
No Evidence for the Presence of Flavobacterium psychrophilum within Ayu Eggs
}

\author{
Akira Kumagai $^{1,3 *}$, Chihaya Nakayasu ${ }^{1}$ and Norihisa Oseko ${ }^{2}$ \\ ${ }^{1}$ Inland Station, National Research Institute of Aquaculture, Fisheries Research Agency, \\ Tamaki, Mie 519-0423, Japan \\ ${ }^{2}$ National Research Institute of Aquaculture, Fisheries Research Agency, \\ Nansei, Mie 516-0193, Japan \\ ${ }^{3}$ Present address:Miyagi Prefectural Freshwater Fisheries Experimental \\ Station, Taiwa, Miyagi 981-3625, Japan
}

(Received May 20, 2004)

\begin{abstract}
This study was made to clarify a possibility of vertical transmission of bacterial coldwater disease (BCWD) in ayu Plecoglossus altivelis. The presence of Flavobacterium psychrophilum on the surface and in the contents of unfertilized and fertilized eggs, which were obtained from ayu naturally carrying $F$. psychrophilum, was examined by a culture method. The bacterium was detected on the egg surface of 19 out of 65 unfertilized egg samples and of 5 out of 30 fertilized egg samples (300 eggs/sample). On the other hand, F. psychrophilum was not detected from the surface of eggs disinfected by povidone-iodine ( $5 \mathrm{ppm}, 10 \mathrm{~min}$ ) or hydrogen peroxide (150 ppm, $30 \mathrm{~min})$. The bacterium was not detected in the contents of these surface-disinfected eggs. These results suggest that $F$. psychrophilum is not transmitted through intra-ovum infection in ayu eggs. Therefore, disinfection of eggs is useful to prevent the vertical transmission of BCWD in ayu hatcheries.
\end{abstract}

Key words: Flavobacterium psychrophilum, bacterial coldwater disease, intra-ovum infection, disinfection of eggs, Plecoglossus altivelis, BCWD

Bacterial cold water disease (BCWD) has been spreading throughout Japan and been causing serious damage to populations of ayu Plecoglossus altivelis in many farms and rivers since the middle of the 1990s. Flavobacterium psychrophilum, the causative agent of BCWD, has been detected from not only ayu but also other wild freshwater fish (lida and Mizokami, 1996; Amita et al., 2000) and cultured salmonid fish (Nematollahi et al.,2003). Ayu is such a popular fish for angling in Japan that a large number of juvenile ayu produced in hatcheries or collected from Lake Biwa, local rivers and the sea coasts are annually released in rivers for the enhancement of ayu stocks. Outbreaks of BCWD occur mainly in rivers where the juveniles carrying the pathogen are released. Therefore, it is important to produce and release juveniles free from the pathogen.

Disinfection of eggs by chemical disinfectants before the introduction of eggs into hatcheries is com- monly used in salmonid fish hatcheries in order to produce the pathogen free juveniles. Such disinfection is likely to be effective in ayu hatcheries. On the other hand, effectiveness of disinfection of the eggs depends on the location where F. psychrophilum exists. In the case that the bacteria have entered eggs, the perfect efficacy of disinfection cannot be expected (Evelyn et al., 1984; Brown et al., 1997; Kumagai et al., 1998). Brown et al. (1997) showed evidence that $F$. psychrophilum was transmitted within salmonid eggs, and Kumagai et al. (2000) demonstrated by the experimental infection that $F$. psychrophilum entered salmonid eggs. However, it remains unclear whether $F$. psychrophilum is transmitted into ayu eggs. We conducted the present study to clarify whether $F$. psychrophilum is present within ayu eggs by cultivating the contents of unfertilized and fertilized eggs obtained from ayu carrying $F$. psychrophilum.

\footnotetext{
* Corresponding author

E-mail: kumagai-ak557@miyagi.pref.jp
} 


\section{Materials and methods}

In vitro bactericidal effect of povidone-iodine and hydrogen peroxide on $\mathrm{F}$. psychrophilum

F. psychrophilum strain FPC840, which was originally isolated from the kidney of ayu in Tokushima, Japan in 1987 (Wakabayashi et al., 1994), was used in the experiment. The bacterium was grown in an enriched Ordal and Anacker's agar (AOAE) plates at $15^{\circ} \mathrm{C}$ for 5 days (Lorenzen and Karas, 1992). The bacterial cells collected from the colonies were suspended in phosphate-buffered saline (PBS) at densities of $2 \times 10^{7}, 2 \times 10^{6}, 2 \times 10^{5} \mathrm{CFU} / \mathrm{mL}$.

Povidone-iodine (Isodine, Meiji Seika Kaisha, Japan) was serially diluted 2 -fold with distilled water at available iodine concentrations between 1.25 and 40 ppm. A half milliliter of the bacterial suspensions was mixed with an equal volume of the serial 2-fold dilutions of povidone-iodine in a 24 well microtitration plate. Following $5,10,15$ and 30 min of incubation at $15^{\circ} \mathrm{C}$, the iodine was neutralized with $0.1 \mathrm{~mL}$ of $\mathrm{N} / 10$ sodium thiosulfate, and then a $0.1 \mathrm{~mL}$ aliquot of the mixture from each well was inoculated on two AOAE plates. After 7 days of incubation at $15^{\circ} \mathrm{C}$, the growth of $F$. psychrophilum was recorded.

Susceptibility of $F$. psychrophilum $\left(2 \times 10^{7} \mathrm{CFU} / \mathrm{mL}\right)$ to hydrogen peroxide (Katayama Kagaku, Japan) at final concentrations of $30,60,90,120,150,180$ and 210 ppm, was examined in the same manner as above except the neutralization with sodium thiosulfate. In order to remove the effect of the hydrogen peroxide on cultivation, the mixture from each well was diluted 10fold with distilled water before inoculation on the plates.

\section{Fish and eggs}

Four lots of mature ayu reared in two hatcheries in the central part of Japan (lot number A1, A2, B1 and B2) were used for the experiments. As the natural occurrence of $B C W D$ had once been recorded in all the lots, many of the experimental fish were expected to carry $F$. psychrophilum. From each mature female (15-20 fish per lot and 65 in total), eggs were aseptically squeezed into individual sterile petri dishes and similarly milt from each male (10-20 fish per lot and 55 in total) was squeezed into individual sterile petri dishes. After taking the eggs and milt, all the parental fish were examined for the bacterium by the following method; the kidneys of the fish were streaked on AOAE medium and incubated at $15^{\circ} \mathrm{C}$ for 7 days.

Approximately 900 unfertilized eggs $(0.3 \mathrm{~g}$ per fish) and $0.1 \mathrm{~mL}$ of milt were taken from each fish of the 4 lots. In 2 lots (A2 and B2, 15 fish for each), the rest of the eggs were inseminated for each individual fish using milt, which was pooled from the 10 or 20 males of the same lot and was diluted 20 -fold with the artificial seminal plasma $\left(\mathrm{NaCl} 130 \mathrm{~mm}, \mathrm{KCl} 40 \mathrm{~mm}, \mathrm{CaCl}_{2} \cdot 2 \mathrm{H}_{2} \mathrm{O} 2.5\right.$ $\mathrm{mm}, \mathrm{MgCl}_{2} \cdot 6 \mathrm{H}_{2} \mathrm{O} 1.5 \mathrm{~mm}, \mathrm{NaHCO}_{3} 2.5 \mathrm{~mm}, \mathrm{pH}$ 8.2). From the inseminated eggs, approximately 3000 fertilized eggs ( $1 \mathrm{~g}$ per fish, 15 fish per lot) were dispensed into $15 \mathrm{~mL}$ sterile tubes as the fertilized egg sample from each fish and were washed 5 times with $10 \mathrm{~mL}$ of sterile distilled water. In the washing process, the tubes were kept shaken to prevent aggregation of the eggs during water-hardening.

Thus, the milt $(0.1 \mathrm{~mL}$ per sample, 55 samples in total), unfertilized eggs (900 eggs per sample, 65 samples in total) and fertilized eggs (3000 eggs per sample, 30 samples in total) were prepared and transported to the laboratory on ice.

Estimation of the number of F. psychrophilum cells in milt and on the surface of unfertilized eggs

Each milt sample (0.1 $\mathrm{mL}$ per sample) was directly inoculated on AOAE plates and incubated at $15^{\circ} \mathrm{C}$ for 7 days.

Each unfertilized egg sample was divided into three batches of 300 eggs each. One of the three batches was vigorously shaken for $30 \mathrm{~s}$ on a vortex stirrer with $0.2 \mathrm{~mL}$ of PBS to detach bacteria from the egg surface. The number of viable bacterial cells released into PBS was determined by AOAE plate count after incubation at $15^{\circ} \mathrm{C}$ for 7 days. Identification of the isolated F. psychrophilum was made by PCR (Toyama et al., 1994) and indirect fluorescent antibody test (IFAT) using an antiserum against $F$. psychrophilum FPC840.

\section{Detection of F. psychrophilum in the egg contents}

The other two batches of the unfertilized eggs taken from each fish were used for the detection of $F$. psychrophilum within the egg contents following a modified protocol of Evelyn et al. (1984) and Brown et al. (1997) as described below. To produce surface-sterile eggs, one batch of unfertilized eggs was treated with 5 ppm povidone-iodine for the lots $A 1$ and $B 1$ and 150 ppm hydrogen peroxide for the lots $A 2$ and B2. After the treatment, eggs were rinsed 3 times with $3 \mathrm{~mL}$ of sterile distilled water, inoculated in $10 \mathrm{~mL}$ of modified Ordal and Anacker broth (Wakabayashi and Egusa, 1974) and incubated at $15^{\circ} \mathrm{C}$ for 3 days. The remaining batch was inoculated and incubated in the broth without disinfection as a control.

After incubation for 3 days, the turbidity of the broth was examined by the eye. Moreover, an aliquot of each broth sample was serially diluted 10-fold with PBS, and $0.1 \mathrm{~mL}$ of each diluted sample was dropped on AOAE plates and incubated at $15^{\circ} \mathrm{C}$ for 7 days. When bacterial colonies grew on the plates, identification of the isolated $F$. psychrophilum was made by PCR and IFAT. Eggs were considered to be surface-sterile when no turbidity in the broth and no subsequent bacterial growth of $F$. psychrophilum on AOAE plates were observed. 
The unfertilized egg samples (300 eggs for each) disinfected as above were homogenized to obtain the egg contents. Each of the homogenates was inoculated in $10 \mathrm{~mL}$ of modified Ordal and Anacker broth, incubated at $15^{\circ} \mathrm{C}$ for an additional 3 days and examined for turbidity. Bacteriological examination using AOAE plate and identification of the isolated $F$. psychrophilum by IFAT and PCR was made in the same manner as above.

Two batches of 300 fertilized eggs each were taken from the two lots (A2 and B2). One batch of fertilized eggs each was disinfected with $150 \mathrm{ppm}$ hydrogen peroxide for $30 \mathrm{~min}$. F. psychrophilum in the egg contents of the surface-sterile eggs were examined in the same manner as used for the unfertilized eggs. The other batch of fertilized eggs each was examined without disinfection as a control.

The influence of disinfection on the survival of ayu eggs

Eggs were collected from 9 mature fish. The eggs of each fish were artificially inseminated in individual sterile petri dishes. Each of 9 inseminated egg samples was divided into two batches of $0.1 \mathrm{~g}$ (approximately 300 eggs). The inseminated egg samples were attached to artificial substances and water-hardened in the hatchery water according to standard hatchery practices. One of two batches (lot 1-5) was disinfected with povidone iodine (5 ppm, $10 \mathrm{~min}$ ) and the other batch (lot 6-9) was disinfected with hydrogen peroxide $(150 \mathrm{ppm}, 30$ $\mathrm{min})$. Control batches were incubated without disinfection. After 10 days of incubation in flowing water at $15^{\circ} \mathrm{C}$, the ratios of live eggs were examined.

\section{Results}

In vitro bactericidal effect of povidone-iodine and hydrogen peroxide on $\mathrm{F}$. psychrophilum

Povidone-iodine solutions completely inactivated $F$. psychrophilum of $10^{7}, 10^{6}$ and $10^{5} \mathrm{CFU} / \mathrm{mL}$ at the available iodine concentration of $20 \mathrm{ppm}$ in $5 \mathrm{~min}, 2.5 \mathrm{ppm}$ in $5 \mathrm{~min}$ and $0.63 \mathrm{ppm}$ in $5 \mathrm{~min}$, respectively. Hydrogen peroxide solutions also completely killed $F$. psychrophilum $\left(10^{7} \mathrm{CFU} / \mathrm{mL}\right)$ at the concentration of 120 ppm in 30 min.

\section{Detection of F. psychrophilum from spawning ayu}

$F$. psychrophilum was isolated from the egg surface and milt as well as kidney (Table 1). The incidence of $F$. psychrophilum on the surface of unfertilized eggs sampled from the 4 lots of 2 hatcheries ranged from $5 \%$ to $47 \%$ (26\% in total), while the incidence in milt was significantly lower than that on the egg surface (Fisher's exact probability test, $p<0.05$ ), ranging from $0 \%$ to $20 \%$ ( $7 \%$ in total). The viable bacterial counts of $F$. psychrophilum in milt and eggs were lower than $10^{3}$ $\mathrm{CFU} / \mathrm{mL}$-milt and $10^{3} \mathrm{CFU} / \mathrm{g}$-eggs, respectively. On the other hand, the incidence of $F$. psychrophilum in the kidney was higher than those on the egg surface and in the milt. There was no significant difference (Fisher's exact probability test, $p>0.05$ ) in the incidence in the kidney between females and males. F. psychrophilum was isolated from the kidney of 11 out of 17 females and 2 out of 4 males whose egg surface or milt was positive for the bacterium.

\section{Detection of F. psychrophilum from disinfected eggs}

F. psychrophilum was detected on the egg surface of 19 unfertilized egg samples out of 65 samples $(29 \%$ in total) and of 5 fertilized egg samples out of 30 samples (17\% in total) (Table 2). By the disinfection with povidone-iodine (5 ppm, $10 \mathrm{~min}$ ) or hydrogen peroxide (150 $\mathrm{ppm}, 30 \mathrm{~min})$, F. psychrophilum on the surface of unfertilized and fertilized eggs was completely killed, although other bacteria remained in some samples. In the egg contents of the surface-sterile egg samples (51 unfertilized egg samples and 27 fertilized egg samples), $F$. psychrophilum was not detected at all (Table 2).

The influence of disinfection on the survival of ayu eggs The ratios of live eggs in the disinfected groups with povidone-iodine $(5 \mathrm{ppm}, 10 \mathrm{~min})$ or hydrogen peroxide (150 ppm, $30 \mathrm{~min}$ ) were not significantly lower $\left(\chi^{2}\right.$ test, $p$ $>0.05$ ) than those of the control groups (Table 3 ).

Table 1. Detection rates of $F$. psychrophilum from spowning ayu

\begin{tabular}{|c|c|c|c|c|c|c|}
\hline \multirow{3}{*}{$\begin{array}{l}\text { Lot } \\
\mathrm{A} 1\end{array}$} & \multicolumn{3}{|c|}{ Female } & \multicolumn{3}{|c|}{ Male } \\
\hline & \multirow{2}{*}{$\begin{array}{l}\text { Kidney \% } \\
53(8 / 15)^{* 1}\end{array}$} & \multicolumn{2}{|c|}{ Egg surface \% } & \multirow{2}{*}{$\begin{array}{r}\text { Kidney \% } \\
47(7 / 15)\end{array}$} & \multicolumn{2}{|c|}{ Milt \% } \\
\hline & & $47(7 / 15)$ & $\left(2 \times 10^{2}\right)^{* 2}$ & & $7(1 / 15)$ & $(2 \times 10)^{* 3}$ \\
\hline $\mathrm{A} 2$ & $87(13 / 15)$ & $40(6 / 15)$ & $\left(6 \times 10^{2}\right)$ & $80(8 / 10)$ & $1(1 / 10)$ & $\left(2 \times 10^{2}\right)$ \\
\hline B1 & $10(2 / 20)$ & $5(1 / 20)$ & $\left(2 \times 10^{2}\right)$ & $0(0 / 20)$ & $0(0 / 20)$ & \\
\hline $\mathrm{B} 2$ & $40(6 / 15)$ & $20(3 / 15)$ & $(2 \times 10)$ & $80(8 / 10)$ & $20(2 / 10)$ & $\left(1 \times 10^{2}\right)$ \\
\hline Total & $45(29 / 65)$ & $26(17 / 65)$ & $\left(3 \times 10^{2}\right)$ & $42(23 / 55)$ & $7(4 / 55)$ & $\left(1 \times 10^{2}\right)$ \\
\hline
\end{tabular}

\footnotetext{
*1 No. of fish positive for F. psychrophilum / No. of fish examined.

*2 Mean no. of live F. psychrophilum (CFU/g) on the egg surface.

*3 Mean no. of live F. psychrophilum (CFU/mL) in the milt.
} 
Table 2. Detection of F. psychrophilum from disinfected ayu eggs

\begin{tabular}{|c|c|c|c|c|c|c|c|c|c|c|c|c|}
\hline \multirow{3}{*}{ Eggs } & \multirow{3}{*}{ Lot } & \multicolumn{7}{|c|}{ Egg surface } & \multicolumn{4}{|c|}{ Egg content } \\
\hline & & \multirow{2}{*}{$\begin{array}{c}\text { No. of } \\
\text { samples* }{ }^{1}\end{array}$} & \multicolumn{3}{|c|}{ Without disinfection } & \multicolumn{3}{|c|}{ Disinfection $* 2$} & \multirow{2}{*}{$\begin{array}{l}\text { No. of } \\
\text { samples*4 }\end{array}$} & \multirow[b]{2}{*}{ F. psychrophilum } & \multirow{2}{*}{$\begin{array}{c}\text { Other } \\
\text { bacteria }\end{array}$} & \multirow[b]{2}{*}{$\begin{array}{c}\text { No } \\
\text { bacteria }\end{array}$} \\
\hline & & & F. psychrophilum & $\begin{array}{c}\text { Other } \\
\text { bacteria }\end{array}$ & $\begin{array}{c}\text { No } \\
\text { bacteria }\end{array}$ & F. psychrophilum & $\begin{array}{c}\text { Other } \\
\text { bacteria }\end{array}$ & $\begin{array}{c}\text { No } \\
\text { bacteria }\end{array}$ & & & & \\
\hline \multirow{5}{*}{$\begin{array}{c}\text { Unfertilized } \\
\text { eggs }\end{array}$} & A1 & 15 & $8(5)^{* 3}$ & 4 & 3 & 0 & 3 & 12 & 12 & 0 & 1 & 11 \\
\hline & $\mathrm{A} 2$ & 15 & $6(4)$ & 6 & 3 & 0 & 2 & 13 & 13 & 0 & 0 & 13 \\
\hline & B1 & 20 & $2(0)$ & 12 & 6 & 0 & 9 & 11 & 11 & 0 & 1 & 10 \\
\hline & $\mathrm{B} 2$ & 15 & $3(0)$ & 0 & 12 & 0 & 0 & 15 & 15 & 0 & 0 & 15 \\
\hline & Total & 65 & $19(9)$ & 22 & 24 & 0 & 14 & 51 & 51 & 0 & 2 & 49 \\
\hline \multirow{3}{*}{$\begin{array}{c}\text { Fertilized } \\
\text { eggs }\end{array}$} & $\mathrm{A} 2$ & 15 & $3(1)$ & 3 & 9 & 0 & 2 & 13 & 13 & 0 & 2 & 11 \\
\hline & B2 & 15 & $2(0)$ & 1 & 12 & 0 & 1 & 14 & 14 & 0 & 3 & 11 \\
\hline & Total & 30 & $5(1)$ & 4 & 21 & 0 & 3 & 27 & 27 & 0 & 5 & 22 \\
\hline
\end{tabular}

*1 Each sample consisted of 300 eggs pooled.

*2 A1 and B1 were disinfected with 5 ppm povidone-iodine for $10 \mathrm{~min}$. A2 and B2 were disinfected with 150 ppm hydrogen peroxide for $30 \mathrm{~min}$.

*3 Number of the samples in which both F. psychrophilum and other bacteria were detected is given in parentheses.

${ }^{*}$ Egg samples, which had been considered to be surface-sterile by disinfection, were examined.

Table 3. Survival rates of fertilized ayu eggs after disinfection

\begin{tabular}{cccc}
\hline \multirow{2}{*}{ Disinfectant } & Lot $^{* 1}$ & \multicolumn{2}{c}{ Ratios of live eggs (\%) } \\
\cline { 2 - 4 } & & Disinfected & Control \\
\hline & 1 & 75.7 & 69.8 \\
Povidone-iodine & 3 & 65.8 & 71.0 \\
(5 ppm, 10 min) & 4 & 57.7 & 64.6 \\
& 5 & 76.7 & 81.3 \\
\cline { 2 - 4 } & mean & 71.2 & 78.3 \\
\hline & 6 & 89.2 & 73.0 \\
Hydrogen peroxide & 7 & 87.6 & 89.7 \\
(150 ppm, 30 min) & 8 & 73.3 & 74.1 \\
& 9 & 68.6 & 64.1 \\
\cline { 2 - 4 } & mean & 79.7 & 78.0 \\
\hline
\end{tabular}

*1 Each sample consisted of 300 fertilized eggs.

\section{Discussion}

F. psychrophilum has been isolated from the reproductive fluid such as the ovarian fluid and/or milt of sexually mature adult salmonids (Holt, 1993; Rangdale et al.,1996; Brown et al., 1997). The bacteria were also detected on the egg surface and in the milt of parental ayu in the present study. If the disinfection of ayu eggs by chemical disinfectants was not carried out, $F$. psychrophilum on the egg surface and in the milt might be transmitted from mature adult ayu to alevins.

In the experiment on the in vitro bactericidal effect of povidone-iodine, the higher concentration of povidoneiodine was needed to kill the higher density of $F$. psychrophilum. However, since the viable bacterial counts of $F$. psychrophilum on eggs and in milt were lower than $10^{3} \mathrm{CFU} / \mathrm{g}$ and $10^{3} \mathrm{CFU} / \mathrm{mL}$, respectively, and $0.63 \mathrm{ppm}$ was enough to kill $10^{5} \mathrm{CFU} / \mathrm{mL}$ of the bacterium in $5 \mathrm{~min}$ in vitro, the treatment with povidone- iodine at a concentration of $5 \mathrm{ppm}$ for 10 min seemed to be enough to disinfect eggs. Treatment with hydrogen peroxide of $150 \mathrm{ppm}$ for $30 \mathrm{~min}$ also exceeded the minimum lethal concentration $(120 \mathrm{ppm})$ for the bacteria of $10^{7} \mathrm{CFU} / \mathrm{mL}$ in vitro. Both the treatments with povidone-iodine (5 ppm, $10 \mathrm{~min})$ and hydrogen peroxide (150 ppm, $30 \mathrm{~min}$ ) showed complete efficacy to kill F. psychrophilum on the surface of ayu eggs. Furthermore, both the treatments did not affect the survival of the fertilized eggs of ayu. From these results, it is clear that the treatments with povidone-iodine and hydrogen peroxide can eliminate $F$. psychrophilum located on the surface of fertilized egg without affecting the survival of the eggs.

F. psychrophilum was not isolated from the contents of the unfertilized eggs, when the egg surface had been disinfected completely. There was no evidence that the bacteria had entered the eggs in the ovary of female ayu before spawning. Thus, it was suggested that intra-ovum vertical transmission is absent in BCWD in ayu. On the other hand, in salmonid fishes, F. psychrophilum has been shown to enter unfertilized eggs before spawning (Brown et al., 1997). Renibacterium salmoninarum, the causative agent of bacterial kidney disease (BKD), was speculated to enter salmonid eggs via the vitelline membrane in the early oogenesis stage and/or via the micropyle in the late oogenesis stage (Evelyn et al., 1984), but the mechanism responsible for the intra-ovum infection has not been fully clarified yet. The mechanism by which the pathogenic bacteria enter pre-spawned eggs is a rewarding area of investigation.

F. psychrophilum was not detected in the contents of the eggs disinfected with povidone-iodine or hydrogen peroxide after insemination with infected milt. The result shows that the bacterium present on the egg sur- 
face and in the milt could not enter the eggs in the process of the fertilization and the water-hardening. Evelyn et al. (1984) reported that the chance of $R$. salmoninarum entering the egg would be favored by the presence of a large population $\left(10^{9} \mathrm{cells} / \mathrm{mL}\right)$ of the bacterium in the coelomic fluid of the parental fish. The lack of intra-ovum infection by $F$. psychrophilum may be due to the fact that amount of the bacteria on ayu eggs were lower $\left(10^{3} \mathrm{CFU} / \mathrm{g}\right)$ than that of $R$. salmoninarum in coho salmon Oncorhynchus kisutch investigated by Evelyn et al. (1984). Furthermore, even when fertilized ayu eggs were water-hardened in a suspension $\left(10^{8}\right.$ $\mathrm{CFU} / \mathrm{mL}$ ) of $F$. psychrophilum, entrance of the bacterium into the eggs did not occur (Kumagai and Nakayasu, unpublished data), although the bacterium successfully entered into coho salmon eggs by the same treatment (Kumagai et al., 2000). Ayu eggs respond to sperm penetration by forming a fertilization cone in the micropyle (Kudo, 1983) and fertilization envelope extract of ayu eggs has bactericidal and fungicidal effects (Kudo and Inoue, 1989; Kudo and Teshima, 1991). These characters of ayu eggs might have prevented $F$. psychrophilum from passing into ayu eggs via the micropyle while being fertilized and during water-harding.

Holt (1993) and Kumagai and Takahashi (1997) reported that iodine treatment of salmonid eggs could not prevent BCWD in subsequent fry, because $F$. psychrophilum entered the eggs. On the other hand, disinfection of the egg surface by iodine or hydrogen peroxide will be effective for the prevention of BCWD in ayu, as indicated in the present study. However, ayu fertilized eggs are attached onto a fibrous substrate with organic materials during incubation in hatcheries. It is well known that the bactericidal activities of these disinfectants are reduced by the presence of organic materials. Furthermore, the presence of the fibrous substrate may prevent the disinfectants from reaching all the surface of the attached eggs. Further work is needed to establish the practical hatchery method for disinfection of ayu eggs.

\section{Acknowledgements}

We are grateful to Mr. Y. Nakai (Gifu Prefectural Fresh Water Fish Research Institute) for providing the important information and Dr. T. Yoshinaga (The University of Tokyo) who kindly reviewed the manuscript.

\section{References}

Amita, K., M. Hoshino, T. Honma and H. Wakabayashi (2000):
An investigation on the distribution of Flavobacterium psychrophilum in the Umikawa River. Fish Pathol., 35, 193-197.

Brown, L. L., W. T. Cox and R. P. Levine (1997): Evidence that the causal agent of bacterial cold-water disease Flavobacterium psychrophilum is transmitted within salmonid eggs. Dis. Aquat. Org., 29, 213-218.

Evelyn, T. P. T., J. E. Ketcheson and L. Prosperi-Porta (1984): Further evidence for the presence of Renibacterium salmoninarum in salmonid eggs and for the failure of povidone-iodine to reduce the intra-ovum infection rate in water-hardened eggs. J. Fish Dis., 7, 173-182.

Holt, R. A., J. S. Rohovec and J. L. Fryer (1993): Bacterial coldwater disease. In "Bacterial diseases of fish" (ed. by V. Inglis, R. J. Roberts and N. R. Bromage). Blackwell Sci. Publ., London, pp. 3-22.

lida, Y. and A. Mizokami (1996): Outbreaks of coldwater disease in wild ayu and pale chub. Fish Pathol., 31, 157164.

Kudo, S. (1983): Response to sperm penetration of the cortex of eggs of the fish, Plecoglossus altivelis. Dev. Growth Differ., 25, 163-170.

Kudo, S. and M. Inoue (1989): Bactericidal action of fertilization envelope extract from eggs of the fish Cyprinus carpio and Plecoglossus altivelis. J. Exp. Zool., 250, 219-228.

Kudo, S. and C. Teshima (1991): Enzyme activities and antifungal action of fertilization envelope extract from fish eggs. J. Exp. Zool., 259, 392-398.

Kumagai, A. and K. Takahashi (1997): Imported eggs responsible for the outbreaks of cold-water disease among cultured coho salmon in Japan. Fish Pathol., 32, 231-232.

Kumagai, A., K. Takahashi, S. Yamaoka and H. Wakabayashi (1998): Ineffectiveness of iodophore treatment in disinfecting salmonid eggs carrying Cytophaga psychrophila. Fish Pathol., 33, 123-128.

Kumagai, A., S. Yamaoka, K. Takahashi, H. Fukuda and H. Wakabayashi (2000): Waterborne transmission of Flavobacterium psychrophilum in coho salmon eggs. Fish Pathol., 35, 25-28.

Lorenzen, E. and N. Karas (1992): Detection of Flexibacter psychrophilus by immunofluorescence in fish suffering from fry mortality syndrome: a rapid diagnostic method. Dis. Aquat. Org., 13, 231-234.

Nematollahi, A., A. Decostere, F. Pasmans and F. Haesebrouck (2003): Flavobacterium psychrophilum infection in salmonid fish. J. Fish Dis., 26, 563-574.

Rangdale, R. E., R. H. Richards and D. J. Alderman (1996): Isolation of Cytophaga psychrophila, causal agent of rainbow trout fry syndrome (RTFS) from reproductive fluids and egg surfaces of rainbow trout (Oncorhynchus mykiss). Bull. Eur. Ass. Fish Pathol., 16, 63-67.

Toyama, T., K. Kita-Tsukamoto and H. Wakabayashi (1994): Identification of Cytophaga psychrophila by PCR targeted 16S ribosomal RNA. Fish Pathol., 29, 271-275.

Wakabayashi, H. and S. Egusa (1974): Characteristics of myxobacteria associated with some freshwater fish diseases in Japan. Nippon Suisan Gakkaishi, 40, 751-757.

Wakabayashi, H., T. Toyama and T. lida (1994): A study on serotyping of Flavobacterium psychrophilum isolated from fishes in Japan. Fish Pathol., 29, 101-104. 